\title{
Smart City Research and Library and Information Science. Preliminary Remarks
}

\author{
Mariusz Luterek \\ Department of Information Studies \\ Faculty of Journalism, Information and Book Studies \\ University of Warsaw, Poland
}

\begin{abstract}
Purpose/Thesis: The purpose of this paper is to analyze the smart city research field from the point of view of library and information science (LIS), based on available scholarly publications.

Approach/Methods: Based on the literature review, the following issues have been described: the smart city concept; the shift of smart cities from strictly technological orientation to that focused on the citizen, the role of smart governance, public libraries as a part of knowledge infrastructure and the current contribution of LIS to this research field.

Results and conclusions: Smart cities are still an emerging research domain. Not only the number of research publications is limited, but also their scope. LIS has been very little involved in a "smart city" research domain so far, and at the same time general literature on "smart cities" refers to public libraries in a very limited way. In general, there have been few attempts to relate information science and smart cities so far, and in each case researchers had problems with finding relevant literature. The most important LIS contribution to the field so far comes from the research project done by the team of experts from the Department of Information Science at Heinrich-Heine-University in Düsseldorf (Germany). Originality/Value: The value of this research results from the fact, that there is very little in-depth, holistic research done in this domain by LIS researchers; hence there is almost no recognition of the role of public libraries in so-called smart cities, not only as knowledge hubs for explicit and tacit knowledge, but also as community building institutions. This paper offers first such attempt in the field.
\end{abstract}

\section{Keywords}

Information science. Public library. Research framework. Smart city. Smart library.

Received: 14 June 2018. Reviewed: 4 July 2018. Accepted: 12 July 2018.

\section{Introduction}

Today, more than half of the world's population lives in cities which puts more demand on the infrastructure than ever. How to manage energy, water, transportation, and other networks? How to make public buildings and spaces more effective and friendly? (Manville et al., 2014, 11) At first, the answer seemed to come from information and communication technologies which is just one more instance where techno-centrism takes the lead. However, soon afterwards social factors have started to be noticed and gained on the importance.

Smart Cities, as a research domain, is still emerging. Not only the number of research publications is limited, but also their scope - around $40 \%$ of them are descriptive in nature, 
and $30 \%$ are design-oriented. It can be attributed to the fact that computer science and engineering are two disciplines contributing the most to smart city research (Ojo et al., 2015, 19).

Modern cities often reinvent the concept of the public library, making it an important part of their knowledge infrastructure. For example, the Qatar National Library combines all functions of public libraries, academic libraries, and the national library, both in physical and digital space (Barth et al., 2017, 2818); while Edinburgh's vision of a smart city includes digital libraries which are playing important role in city's regeneration, digital inclusion strategy, and economic development (Zygiaris, 2011, 227).

The purpose of this paper is to analyze the smart city research field from the point of view of library and information science (LIS) and to identify the roles public libraries can play in smart city's development. In the following subsections we will discuss the smart city concept; how smart cities have shifted from strictly technological orientation to putting the citizen in the center, the role of smart governance; public libraries as a part of knowledge infrastructure and what is the input of LIS in this research field.

\section{The smart city concept}

When academic community started discussing the new type of society, which came into shape after WWII, for a long time (and in fact - even now) there was no consensus on how to name it, or what factors were the most important in determining that a society has finished its industrial stage of development. As a result, many battling concepts were introduced to academic discourse: information society, network society, knowledge society, or third wave, just to name a few. Similarly, a new model of urban management led to emergence of many concepts: world city or global city (Tabuchi, 2013), networked city (Mitchell, 2003), digital city (Schuler, 2002), ubiquitous city (Gil-Castineira et al., 2011), informational city (Castells, 1989), knowledge city (Franz, 2008), creative city (Martini, 2016), and - finally - smart city for which the ultimate technological framework is the Internet of Things (Vlacheas et al., 2013). Smart city is used as an umbrella concept for a large spectrum of solutions and programs, involving many technologies and aiming at a wide range of goals (Dameri, 2013) as it is used as a generic term to describe ICT-based urban ecosystems (Zygiaris, 2011).

Smart city is still a fuzzy concept, having its origins rather in marketing than in science (Barth et al., 2017) and as the result, there is no broadly accepted academic definition for this term. For some however, there are three conceptual dimensions of a smart city: technology, people, and community what means that a city becomes smart when "investments in human/social capital and IT infrastructure fuel sustainable growth and enhance quality of life, through participatory governance" (Nam \& Pardo, 2011, 286). However, the final goal for every smart city is to improve citizens' quality of life and environmental preservation (Dameri, 2017, 23).

Surprisingly, smart city is not a new concept. Singapore's vision of a smart city, also known under the term "intelligent island", has been the driving force for implementing national information infrastructure for decades. Singapore is well known for its orientation on ICT and in fact, achieves top positions in most smart cities rankings. Obviously, apart 
from earliest and most comprehensive IT initiatives, its success can be attributed to small size of a country - lack of natural resources has left this small island no other choice than shift towards digital (Tan, 1998).

One of the more interesting approaches to smart cities is a knowledge-based conceptual vision of the smart city where people's information and knowledge are at least as important as ICTs (Negre et al., 2015). According to this vision, systems within cities have to adapt to hyper-connected citizens in an environment going through constant evolution what is quite similar to British "transformational government". One of the problems is that, unlike before, cities nowadays are flooded with data, coming from almost endless number of systems. These data carry knowledge, and smart cities are learning how to tap to it.

As some researchers argue, just as there were typical cities of the industrial society (for example British Manchester, German Dortmund, or Polish Łódź), there are typical cities of the information society. That brings up the concept of informational urbanism which is an interdisciplinary domain, spanning across such disciplines as computer science and information science, but also urban studies, city planning, architecture, city economics, and city sociology (Barth et al., 2017).

Finally, most of the literature and global reports refer to the so-called "world cities" when discussing smart cities solutions, however, this model can be introduced to medium or even small cities with necessary adjustments. The challenges of medium-sized cities can be much different as they seem "to be less well equipped in terms of critical mass, resources and organizing capacity"(Giffinger et al., 2007, 5). After all, information technologies make even medium and small urban units global - or, to use better term - glocal (Stock, 2011, 981).

\section{Smart city - from technology to citizen orientation}

Many researchers argue that the origins of the smart city concept come from environmental protection and sustainability policies, urban planning (Negre et al., 2015, 2318), open government and open innovations concepts, as well as e-participation (Scholl \& Scholl, 2014) societies and their governments around the world have been meeting unprecedented challenges, many of which surpass the capacities, capabilities, and reaches of their traditional institutions and their classical processes of governing. Among these challenges are the need for an accelerated transition of the global economy from its current fossil fuel basis to renewable energies, the so-called post-carbon era also known as the third industrial revolution, the containment and reduction of government spending and debt financing, the increasing rapidity of market changes, and the expanding lag of timely interventions via traditional lawmaking and government action. While upholding the proven principles of Western democracy, democratic self-governance in $21^{\text {st }}$ century market economies apparently needs to develop new institutional formats and novel mechanisms for staying abreast with the systemic dynamics of a tightly interconnected global society. We claim that actionable and omnipresent information along with its underlying technologies are substantial prerequisites and backbones for developing models of smart democracy. As a result, in the beginning "smartness" was referring to solutions allowing to reduce energy consumption and limiting negative impact on the environment (power consumption and transport). However, sustainability in this context is no longer referring just to being 
environmentally friendly and limiting carbon footprint, but also to designing organizational structures and processes, as well as institutional norms that will exist over time in a way that "enriches citizens lives and at the same time prioritizes the efficient use of societal resources" (Webster \& Leleux, 2018, 99).

The private sector is very active in the field of smart cities; however, this interest seems to be driven by each company's need to promote their "smart products":

IBM focuses on ICT and on facilities needed to use data and information for governing a city in a smarter way. Siemens defines a smart city as an energy efficient and $\mathrm{CO}_{2}$-neutral city, therefore focusing on environmental aspects. Ericsson especially speaks about smart connected city; Intel suggests to base a smarter city on ICT and especially on Internet of Things (Dameri, 2017, 27).

IBM went a step further and have trademarked the term "smarter cities" in 2011 (Webster \& Leleux, 2018, 98).

Dimensions of a smart cities pursued by (Giffinger et al., 2007) in their Smart Cities Ranking, include smart economy (understood as a competitiveness), smart people (level of qualification; affinity to life-long learning; social and ethnic plurality; flexibility; creativity; cosmopolitanism/openmindedness; participation in public life), smart governance (and participation), smart mobility (both in terms of transport and ICT), smart environment (attractivity of natural conditions and environmental protection) and smart living (cultural facilities, health conditions, individual safety, housing quality, touristic attractivity and social cohesion). Surprisingly, one of the indicators in the smart people subgroup is "book loans per citizen", while the indicator "cultural facilities" in smart living subgroup refers only to cinemas, museums, and theatres. Several Polish cities have been noticed in the ranking with particularly high scores in the "smart people" category (Tab. 1).

Tab. 1. Final results and performance of Polish cities in "Smart cities Ranking of European medium-sized cities". Source: Giffinger et al., 2007, 16

\begin{tabular}{|l|c|c|c|c|c|c|c|}
\hline \multicolumn{1}{|c|}{ City } & $\begin{array}{c}\text { Smart } \\
\text { Economy }\end{array}$ & $\begin{array}{c}\text { Smart } \\
\text { People }\end{array}$ & $\begin{array}{c}\text { Smart } \\
\text { Governance }\end{array}$ & $\begin{array}{c}\text { Smart } \\
\text { Mobility }\end{array}$ & $\begin{array}{c}\text { Smart } \\
\text { Environment }\end{array}$ & $\begin{array}{c}\text { Smart } \\
\text { Living }\end{array}$ & Total \\
\hline RZESZÓW & 69 & 19 & 53 & 41 & 56 & 50 & 48 \\
\hline BIALYSTOK & 67 & 22 & 59 & 56 & 47 & 55 & 53 \\
\hline BYDGOSZCZ & 68 & 27 & 57 & 46 & 52 & 61 & 57 \\
\hline SZCZECIN & 65 & 52 & 58 & 43 & 59 & 56 & 62 \\
\hline KIELCE & 63 & 56 & 56 & 57 & 62 & 54 & 64 \\
\hline
\end{tabular}

Smart cities are inhabited by knowledge-citizens what forces local governments to consider not only explicit knowledge (so - knowledge deducted from data flows), but also tacit knowledge (citizen's knowledge) (Negre et al., 2015, 2318). Access to explicit knowledge can be provided through information booklets, brochures, websites, documents, and other physical materials; while transfer of tacit knowledge in general requires personal contact and socialization (Kumaresan \& Swrooprani, 2013, 2). Tapping to the latter seems to be the most current challenge for a smart city: how to create favorable conditions to support sharing tacit knowledge? How to transform tacit knowledge into explicit knowledge? After all, people's needs, behavior patterns, their opinions, and expectations can play an important role in creating better living conditions (Negre et al., 2015, 2320). 
There is not enough research regarding effective strategies for the participatory governance of cities, including smarter ways to use the potential of citizens and companies. At the same time, as literature shows

best cities of the world to live in are not the ones with the most advanced technological layers but cities that create an atmosphere were citizens, companies and government build a vital and sustainable city in close collaboration (Effing \& Groot, 2016, 242).

Surveys show that quite often people are not at the center of the smart city initiatives and that key actors (companies, local officials) are more interested in pursuing their own goals. Few people are aware of smart city projects being implemented in their area what is a result of lack of information on them, lack of support in using smart devices and services, and lack of incentives to participate in co-creation process (Dameri, 2017, 40). You have to agree with the opinion of Chourabi et al. that

Addressing the topic of people and communities as part of smart cities is critical, and traditionally has been neglected at the expense of understanding more technological and policy aspects of smart cities (Chourabi et al., 2012, 2293).

The authors refer to a list of factors related to smart cities and people and communities as found in the literature: digital divide, information and community gatekeepers, participation and partnership, communication, education, quality of life, accessibility.

In this context, it is worth taking the example of Singapore, as a source of inspiration. Following its Government Computerization Programme, the country has introduced several IT implementation phases, starting from the year 1980. At first, their goal was to set up the information infrastructure and increase its usage; however, as early as in the beginning of 1990s, their aims shifted to more human - and business-oriented ones, including improving quality of life (making work more efficient and interacting with institutions) and enhancing potential of individuals (strengthening the knowledge and skills potential of every individual) (Tan, 1998, 234). Thus, Singapore is a very good example of how a smart city can change its orientation from technology to human.

For people to be "smart" means

[to be] able to profitably use new technologies and to create smart intellectual capital to support smart economic and social development in their city. To include people in the smart city definition means to drive the local and central government to invest in increasing knowledge economy and in reducing the digital divide, to obtain a higher digital response by citizens (Dameri, 2013, 2547).

In fact, many factors play roles in "smart people" concept: affinity to life-long learning, social and ethnic plurality, flexibility, creativity, cosmopolitanism or open-mindedness, and participation in public life (Nam \& Pardo, 2011, 287). "Public bodies should create the best conditions for implementing a smart city for all, reducing the digital divide and promoting smart social inclusiveness" (Dameri, 2017, 36).

\section{Smart governance}

Researchers agree that third industrial revolution has changed the landscape of how cities work and as a result, new and effective mechanisms of regulation need to be introduced, ones that keep up with rapid changes and developments. Traditional means of making, enforcing, interpreting and implementing the law have proven to be outdated (Scholl \& Scholl, 2014, 164). 
Smart cities require smart governance, as proposed in the roadmap for research and practice (Scholl \& Scholl, 2014, 167). This document has been heavily influenced by the President Barack Obama's Memorandum on Transparency and Open Government (Obama, 2009). Scholl and Scholl have raised a question of what information sharing policies are needed for enabling and maintaining smart governance. A shared, timely, and actionable information is quintessential for inter - and intra-governmental collaboration as well as for G2C and G2B interactions (Scholl \& Scholl, 2014, 169). Furthermore, such information sharing requires human skills, like a high-level technical and information literacy.

Open government includes not only open information, but also open innovations. In a smart city environment it means citizen-driven innovations and requires knowledgeable and creative human capital - so that all actors can play their own role in multilayer innovation ecosystem (Dameri, 2017, 29). This idea is close to another concept - co-production, which in turn comes from understanding that small, local communities require a different approach than a top-down bureaucratic management (Webster \& Leleux, 2018, 100). In general, the smart city is a concept that changes the traditional way of urban management, by switching it from a top-down to a bottom-up approach through citizen empowerment (Webster \& Leleux, 2018, 99).

In recent years we have been observing a growing interest in using smart city solutions to engage citizens and to allow them to participate directly (without the intermediation from NGOs for example) in a coproduction of services, laws, and policies. It goes much beyond online voting and consultations, referred to as e-participation; and involves more innovative mechanisms like social media, living labs, citizen dashboards, maker spaces, or gamification (Webster \& Leleux, 2018). When relying so heavily on ICT in citizen's involvement, the voice of those digitally excluded (or digitally less savvy) can be lost. So smart cities introduce innovative participatory spaces where the digital and physical are blended together, and through which citizens, no matter what their level of ICT literacy is, can influence the process of shaping public policies and services. Furthermore, certain groups within society present different level of interest in participation. Most notably, citizens from more bourgeois areas are more interested in stating or sharing their opinions and needs than those from less affluent areas (Webster \& Leleux, 2018, 97). Some research shows that public officials "take almost habitual account of middle-class needs and demands" over lower-class needs (Hastings et al., 2014, 219). At the same time, public libraries can facilitate local participation, like in case of Central Library 'M. L. Kropivnitskiy' \& the Mykolayiv Centralized Library System for Adults (Ukraine) where Citizen Service Center encourages online interaction with government officials (EIFL, 2016, 23).

After the technological development stage of smart cities, it became clear, and it is now broadly recognized that people and their interactions are critical factors in a modern city's success. What in turn results in a more organized approach to involving people by offering them services accessible to all citizens, no matter what kind of barrier they face (related to language, culture, information skills, education, etc.) (Nam \& Pardo, 2011, 288). For example data literacy deficit is one of the main reasons why the open government does not bring expected results, both in case of public officials providing data sets and citizens and their ability to use and interpret data (Webster \& Leleux, 2018, 101). 


\section{Public libraries as a part of knowledge infrastructure in a smart city}

According to Negre et al. (2015, p. 2322), there are two networks of information overlap in a smart city: a formal information network between the internal or external entities, and informal information network between nomadic or sedentary citizens. As a result, the city's information and knowledge consist mainly of 1) a digital information system, 2) individuals who are processors of data to which they give sense under the form of information, and 3) a knowledge system that includes tacit knowledge of individuals and explicit knowledge. Thus, social infrastructure (intellectual capital and social capital) is an indispensable endowment to smart cities which are "humane cities" (Nam \& Pardo, 2011, 285).

Libraries are traditional institutions responsible for knowledge organization, storage and dissemination. Moreover, they provide access to constantly growing, high quality digital information, and physical working, meeting and learning spaces (Mainka \& Khveshchanka, 2012). Public libraries are staying relevant in information society not only because they provide access to the explicit knowledge, but also because: (1) they are important physical spaces for the local communities, (2) they actively develop community networks and social capital, (3) they limit digital divide by providing access to ICTs and developing information skills of their users. Furthermore, "their capacity to facilitate and foster broader, more creative interaction makes them valuable for health, well-being and livability of urban environments (Houghton et al., 2013, 28). Libraries provide limited access the global explicit knowledge through databases, but at the same time they can act as creative spaces allowing sharing implicit information (Stock, 2011). In fact,

[...] the prototypical public library in the knowledge society has two core services: 1) to support citizens, companies and administrations in their city and region with digital services, namely e-resources as well as reference services, and to communicate with their customers via social media; and 2) to provide physical spaces for meeting, learning and working, as well as areas for children and other groups, in a building that is a landmark of a city (Mainka et al., 2013, 295).

For others, however, the role of public libraries is gradually diminishing as information technology progresses (Basri et al., 2012).

It is obvious that both modern society and economy require knowledge infrastructure which may but does not have to include also public libraries. According to Mainka \& Khveshchanka (2012), libraries can play a fundamental role in the knowledge society, becoming knowledge hubs, both in physical and digital world. In regard to e-resources, the authors describe two models allowing access 24/7. The first one provides users with unlimited access from their personal devices (introduced e.g. in Reykjavik); while the second one limits access to library's computers (e.g. in Singapore). Based on their research, Mainka \& Khveshchanka have identified nine factors relevant in comparing digital libraries: number of e-databases offered by the public library, annual expenditure on e-resources, number of languages in which the library website is available, user's cost of access to e-resources, online provision of video-tutorials on how to use e-resources, provision of guides on how to use e-resources, provision of seminars on information literacy, types of digital references being offered, and marketing activities in use (Mainka \& Khveshchanka, 2012, 4). Smart cities require strategic vision leading to knowledge-based urban development involving robust public libraries networks, among others (Stock, 2011, 978). 
Furthermore, many authors have discussed the economic value of public libraries often regarded as a part of the soft location factor for companies - if there is a library in a city it will not be recognized; but if there is no library (or it has been closed) it will be seen as disadvantage (Mainka et al., 2013, 298).

A good example of strategic approach to establishing digital public libraries is TiARA (Timely Information for All, Relevant and Affordable) initiative, launched in 1998 in Singapore. Its goal was to provide access to academic and professional databases for students and everyone else interested what in return, will form the foundations of a knowledge economy in Singapore (22 local libraries were equipped with these services) (Tan, 1998, 241). Today's users of public libraries in Singapore, through eResources service, have access not only to e-databases, e-books, and e-journals, but also to e-learning (LyndaLibrary, a video library with engaging, top-quality courses taught by recognized industry experts) as well as to Digital Business Library (National Library Board, 2018).

In many countries community building is high on the agenda of public library sector (Polderman et al., 2014), and patronage of libraries is increasing - people need them not only for information, but also for leisure and social interaction (Houghton et al., 2013, 29). By Mainka et al.

The role of the public library in a smart city is to keep people and companies informed on all aspects of "smart" developments and to educate their users in information literacy,

and furthermore, by developing two forms of public spaces: physical and digital, they enhance community development (Mainka et al., 2013, 299). In case of digital space, community building can be based on e.g. social media, such as Facebook, YouTube, Twitter, through posting and interaction with users (Peters et al., 2013).

As stated in Lyon Declaration on Access to Information and Development (2014)

increased access to information and knowledge, underpinned by universal literacy, is an essential pillar of sustainable development. Greater availability of quality information and data and the involvement of communities in its creation will provide a fuller, more transparent allocation of resources.

Although the Declaration... does not mention "smart cities", it underlines the role of public libraries as institutions that not only provide access to various types of information, but also connect stakeholders, identify and focus attention on relevant needs of local communities, or provide public forums and space for wider civil society participation, among others.

\section{Library and information science in the "smart city" research field}

Smart cities need smart libraries, and smart libraries have to employ smart librarians. However, LIS has been very little involved in a "smart city" research domain so far; and at the same time, the literature on "smart cities" refers to public libraries in a very limited way (Johnson, 2012). In general, there have been few attempts to connect information science and smart cities so far, and in each case researchers had problems with finding relevant literature (Stock, 2011, 963) Johnson, using smart city dimensions (Giffinger et al., 2007), introduced some research questions in relation to role of public libraries in each of those aspects. Some examples of them are presented in the Table 2. 
For LIS researchers it is obvious that information science methodology can be applied to address research questions in any information-based domain. However, this knowledge is rather tacit then explicit one and is rarely presented in organized and structured way. The Table 3 presents ways in which LIS can be used in "smart city" research domain, as suggested by W. G. Stock.

Tab. 2. Research questions on the role of public libraries in smart cities.

Source: Own elaboration, based on (Johnson, 2012)

\begin{tabular}{|l|l|}
\hline \multicolumn{1}{|c|}{$\begin{array}{c}\text { Smart City } \\
\text { dimension }\end{array}$} & \multicolumn{1}{c|}{ Research questions } \\
\hline Smart people & How can library services help to keep them up to date and fully informed? \\
\hline Smart economy & $\begin{array}{l}\text { How could an appropriate infrastructure be developed to facilitate a collec- } \\
\text { tive response from all a city's libraries and information services to the city's } \\
\text { wide range of social, cultural, scientific, and economic needs? }\end{array}$ \\
\hline $\begin{array}{l}\text { Smart mobility } \\
\text { /smart } \\
\text { environment }\end{array}$ & $\begin{array}{l}\text { How could the role of research libraries and information centers be enhanced } \\
\text { to enable researchers, professionals, and administrators in a city to access } \\
\text { relevant current information about technological trends so that the city's } \\
\text { transport and telecommunication facilities match the best worldwide and so } \\
\text { that environment is not threatened by development? }\end{array}$ \\
\hline $\begin{array}{l}\text { Smart gover- } \\
\text { nance }\end{array}$ & $\begin{array}{l}\text { What kind of information services are needed to keep them informed about } \\
\text { how the government is working for their benefit, and how the public services } \\
\text { that government provides are being delivered effectively, efficiently, and } \\
\text { economically in other cities so that they have a basis for comparison and can } \\
\text { make a balanced judgment on local progress? }\end{array}$ \\
\hline Smart living & \begin{tabular}{l} 
What can the library do to raise awareness of the lifestyle that the city offers? \\
\hline
\end{tabular}
\end{tabular}

Tab. 3. How can information science research be related to smart city research? Source: Own elaboration, based on (Stock, 2011, 982)

\begin{tabular}{|l|l|}
\hline \multicolumn{1}{|c|}{ Information science } & \multicolumn{1}{|c|}{ Smart city research } \\
\hline $\begin{array}{l}\text { Informetrics } \\
\text { and scientometrics }\end{array}$ & $\begin{array}{l}\text { Finding appropriate indicators for a city's position in the internatio- } \\
\text { nal information flows }\end{array}$ \\
\hline Information architecture & $\begin{array}{l}\text { Analyzing and building up community Web sites and their naviga- } \\
\text { tion systems }\end{array}$ \\
\hline $\begin{array}{l}\text { Knowledge organization } \\
\text { and information retrieval }\end{array}$ & $\begin{array}{l}\text { Supplying right pieces of knowledge in every decision-making } \\
\text { process }\end{array}$ \\
\hline Knowledge management & $\begin{array}{l}\text { Analyzing and organizing the dissemination and sharing of infor- } \\
\text { mation inside the community; importing explicit knowledge }\end{array}$ \\
\hline User research & Estimating information needs \\
\hline Information marketing & Informing interested parties about libraries offerings \\
\hline $\begin{array}{l}\text { Sociology of information } \\
\text { and information ethics }\end{array}$ & $\begin{array}{l}\text { Analyzing social consequences of the "smart" revolution (e.g. digital } \\
\text { divide) }\end{array}$ \\
\hline Information literacy & Reducing negative social consequences of the "smart" revolution \\
\hline
\end{tabular}


Smart city research lacks essential knowledge on digital libraries, knowledge representation, information dissemination, and knowledge management (Stock, 2011, 981). LIS may support smart city research in these aspects.

So far, the most important LIS input to the field comes from the research project undertaken by the experts from the Department of Information Science at Heinrich-Heine-University Düsseldorf in Germany (Agnes Mainka, Sarah Hartmann, Lisa Orszullok, Isabella Peters, Anika Stallmann, and Wolfgang G. Stock). In their study, they used two research questions: (1) What core services of the physical library are provided in typical cities of the knowledge society? (2) What core services of the digital library are provided in typical cities of the knowledge society.

\section{Conclusions and future work}

There is a clear need for future work on the role of public libraries in smart cities, the roles they can play, and the services they can offer. It will lead to build a conceptual framework for a smart library. There has been not much in-depth, holistic research done in this domain by LIS researchers, so there is almost no recognition of the role of public libraries in the so-called smart cities, not only as knowledge hubs for explicit and tacit knowledge but also as community building institutions. Better understanding of what roles libraries can play in a modern society where citizen-empowerment driven by ICT is a major factor, will help in rebuilding the image of public libraries. Some research questions that can be asked, include: what makes a city smart, and what is the role of public libraries in this process? What research agenda would support the development of smart libraries? What makes a public library smart? What core library services are provided in a typical smart city? Are there any typical (prototypical) smart libraries? In what ways are public libraries enhancing information and digital skills of citizens in smart cities, thus limiting digital divide? In what ways do public libraries use their community building function to foster bottom-up approach in smart cities? In what ways do public libraries use their community building function to foster open innovations? In which ways are public libraries included in strategies for smart city development? Is there one model for a "smart library", or should it be differentiated based on city's size? Do librarians in public libraries in smart cities perceive their libraries as important actors in developing smart city? What should smart library's conceptual framework consist of?

However, in case of information science, the problem seems to be different in nature. As shown above, such aspects of LIS research like informetrics and scientometrics, information architecture, knowledge organization and information retrieval, knowledge management, user research, information marketing, sociology of information and information ethics, or information literacy can be easily linked with "smart city" research. That does not change the fact that only few researchers working in "smart city" research field identify themselves as LIS researchers. 


\section{References}

Barth, J., Fietkiewicz, K., Gremm, J., Hartmann, S., Ilhan, A., Mainka, A., Meschede, C., Stock, W. (2017). Informational Urbanism. A Conceptual Framework of Smart Cities [online]. Proceedings of the 50th Hawaii International Conference on System Science (HICSS-50). Waikoloa Village, Hawaii, USA. [16.05.2018] http://hdl.handle.net/10125/41496

Basri, M., Yusof, Z. M., Zin, N. A. M. (2012). Information Policy: The Diminishing Role of Library. International Journal of Humanities and Social Science, 2(19), 317-327.

Castells, M. (1989). The Informational City: Economic Restructuring and Urban Development. Oxford: Blackwell Publishers.

Chourabi, H., Nam, T., Walker, S., Gil-Garcia, R. J., Mellouli, S., Nahon, K., Pardo, T.A., Scholl, H. J. (2012). Understanding Smart Cities: An Integrative Framework [online]. In 45th Hawaii International Conference on System Sciences (2289-2297). [16.05.2018] https://www.researchgate. net/publication/254051893_Understanding_Smart_Cities_An_Integrative_Framework; DOI: 10.1109/HICSS.2012.615

Dameri, R. P. (2013). Searching for a Smart City Definition: a Comprehensive Proposal. International Journal of Computers \& Technology, 11(5), 2544-2551.

Dameri, R. P. (2017). Smart City Implementation. Cham: Springer International Publishing AG.

Effing, R., Groot, B. P. (2016). Social Smart City: Introducing Digital and Social Strategies for Participatory Governance in Smart Cities. In: H. J. Scholl, O. Glassey, M. Janssen, B. Klievink, I. Lindgren, P. Parycek, D. Sa Soares (eds.), Electronic Government: Proceedings of the 15th IFIP WG 8.5 International Conference, EGOV 2016. Guimarães, Portugal: Springer International Publishing.

Franz, P. (2008). From University Town to Knowledge City: Strategies and Regulatory Hurdles in Germany. In: T. Yigitcanlar, K. Velibeyoglu, S. Baum (eds.), Knowledge-Based Urban Development: Planning and Applications in the Information Era (101-115). IGI Global.

Giffinger, R., Fertner, C., Kramar, H., Kalasek, R., Pichler-Milanović, N., Meijers, E. (2007). Smart Cities: Ranking of European Medium-Sized Cities. Vienna: Delft University of Technology.

Gil-Castineira, F., Costa-Montenegro, E., Gonzalez-Castano, F., López-Bravo, C., Ojala, T., Bose, R. (2011). Experiences inside the Ubiquitous Oulu Smart City. Computer, 44(6), 48-55.

Hastings, A., Bailey, N., Bramley, G., Croudace, R., Watkins, D. (2014). "Managing” the Middle Classes: Urban Managers, Public Services and the Response to Middle-Class Capture. Local Government Studies, 40(2), 203-223. DOI: 10.1080/03003930.2013.815615

Houghton, K., Foth, M., Miller, E. (2013). The continuing relevance of the library as a third place for users and non-users of IT: the case of Canada Bay. The Australian Library Journal, 62(1), 27-39.

Johnson, I. M. (2012). Smart Cities, Smart Libraries, and Smart Librarians [online]. In: Shanghai International Library Forum. Shanghai, China. [16.05.2018] http://eprints.rclis.org/20429/

Kumaresan, C., Swrooprani, B. (2013). Knowledge Sharing and Factors Infuencing Sharing in Libraries - A Pilot Study on the Knowledge Sharing Attributes of the EducationCity Library Community in Qatar. Journal of Information E Knowledge Management, 12(1), 1-13.

Lyon Declaration on Access to Information and Development (2014). [online] IFLA. [16.05.2018] https://www.lyondeclaration.org/

Mainka, A., Hartmann, S., Orszullok, L., Peters, I., Stallman, A., Stock, W. G. (2013). Public Libraries in the Knowledge Society: Core Services of Libraries in Informational World Cities. Libri, 64(4), 295-319. DOI: 10.1515.libri-2013-0024

Mainka, A., Khveshchanka, S. (2012). Digital Libraries as Knowledge Hubs in Informational Cities. [online] In: Libraries in the Digital Age (LIDA), Proceedings Vol. 12. Zadar: University of Zadar. http://ozk.unizd.hr/proceedings/index.php/lida/article/view/6/96

Manville, C., Cochrane, G., Cave, J., Millard, J., Pederson, J., Thaarup, R. (2014). Mapping Smart Cities in the EU. Brussels: Directorate General for Internal Policies, European Parliament. 
Martini, L. (2016). Knowledge Sharing in a Creative City. Procedia Computer Science, 99, 79-90. DOI: $10.1016 /$ j.procs.2016.09.102

Mitchell, W. J. (2003). Me++: The Cyborg Self and the Networked City. Cambridge, Mass.: MIT Press.

Nam, T., Pardo, T. A. (2011). Conceptualizing Smart City with Dimensions of Technology, People, and Institutions. [online] 12th Annual International Conference on Digital Government Research (Dg.o 2011). College Park, MD, USA: ACM. [16.05.2018] https://dl.acm.org/citation.cfm?doid $=2037556.2037602$

National Library Board (2018). [online] [14.05.2018] https://www.nlb.gov.sg/

Negre, E., Rosenthal-Sabroux, C., Gascó, M. (2015). A Knowledge-Based Conceptual Vision of the Smart City. Proceedings of the 48th Hawaii International Conference on System Sciences (HICSS-48). Washington, DC: IEEE Computer Society.

Obama, B. (2009). Transparency and Open Government. Memorandum for the Heads of Executive Departments and Agencies. [online]. [16.05.2018] https://obamawhitehouse.archives.gov/the-press-office/transparency-and-open-government

Ojo, A., Dzhusupova, Z., Curry, E. (2015). Exploring the Nature of Smart Cities Research Landscape. In: R. J. Gil-Garcia, T. A. Pardo, T. Nam (eds.), Smarter as the New Urban Agenda: A Comprehensive View of the 21st Century City (1-27). Berlin Heidelberg: Springer-Verlag.

Peters, I., Hartmann, S., Mainka, A. (2013). Social Media Use and Outreach of Selected Public Libraries in Informational World Cities. In: Proceedings of the Second Association for Information Science and Technology ASISET European Workshop (79-93).

Polderman, M., Duijnhoven, H. van, Huysmans, F. (2014). Community Building for Public Libraries in the 21st Century: Examples from The Netherlands. [online] [16.05.2018] https://www.ifla.org/files/ assets/public-libraries/publications/community_building_for_public_libraries_in_the_21st_century_polderman_et_al.pdf

EIFL (2016). Public Libraries Advancing Community Development in Europe [online]. Electronic Information for Libraries, [12.07.2018], http://www.eifl.net/system/files/resources/201603/europe_summaries-final-web.pdf

Scholl, H. J., Scholl, M. (2014). Smart Governance: A Roadmap for Research and Practice. [online] In: iConference 2014 Proceedings (163-176). [16.05.2018] https://www.ideals.illinois.edu/bitstream/ handle/2142/47408/060_ready.pdf?sequence=2DOI: 10.9776/14060

Schuler, D. (2002). Digital Cities and Digital Citizens. In: M. Tanabe, P. Van den Besselaar, \& T. Ishida (Eds.), Digital Cities (71-85). Berlin Heidelberg: Springer-Verlag.

Stock, W. G. (2011). Informational Cities: Analysis and Construction of Cities in the Knowledge Society. Journal of American Society for Information Science and Technology, 62(5), 963-986. DOI: $10.1002 /$ asi.21506

Tabuchi, T. (2013). Agglomeration in World Cities. Procedia - Social and Behavioral Sciences, 77, 299-307. DOI: $10.1016 /$ j.sbspro.2013.03.088

Tan, M. (1998). Plugging into the Wired World: Perspectives from the Singapore. Information Communication E Society, 1(3), 217-245. DOI: 10.1080/13691189809358968

Vlacheas, P., Giaffreda, R., Stavroulaki, V., Kelaidonis, D., Foteinos, V., Poulios, G., Demestichas, P. (2013). Enabling Smart Cities through a Cognitive Management Framework for the Internet of Things. IEEE Communications Magazine, 51(6), 102-111.

Webster, C. W. R., Leleux, C. (2018). Smart Governance: Opportunities for Technologically-Mediated Citizen Co-production. Information Polity, 23, 95-110. DOI: 10.3233/IP-170065

Zygiaris, S. (2011). Smart City Reference Model: Assisting Planners to Conceptualize the Building of Smart City Innovation Ecosystem. Journal of the Knowledge Economy, 2(2), 217-231. 


\title{
Badania nad inteligentnymi miastami z punktu widzenia bibliologii i informatologii
}

\begin{abstract}
Abstrakt
Cel/Teza: Celem artykułu jest scharakteryzowanie badań prowadzonych w zakresie tzw. inteligentnych miast (smart cities) z punktu widzenia bibliologii i informatologii, na podstawie dostępnej literatury naukowej.

Koncepcja/Metody badań: Na podstawie analizy literatury opisane zostały takie zagadnienia, jak: koncepcja inteligentnego miasta, jej przeorientowanie z technologii na obywatela, rola inteligentnego zarządzania w mieście, biblioteki publiczne jako część infrastruktury wiedzy oraz wkład bibliologii i informatologii w aktualny stan wiedzy.

Wyniki i wnioski: Inteligentne miasto, jako pole badawcze, nadal pozostaje w fazie kształtowania. Liczba publikacji na ten temat, jak również ich zakres są ograniczone. Bibliologia i informatologia była dotychczas $\mathrm{w}$ tym obszarze zaangażowana w bardzo ograniczonym stopniu, natomiast pozostała literatura odnosi się sporadycznie do bibliotek publicznych. Nieliczne próby powiązania bibliologii i informatologii z omawianym polem badawczym napotykały na problem braku literatury. Najważniejszym dotychczas zrealizowanym projektem dotyczącym tego zagadnienia było badanie przeprowadzone przez naukowców z Instytutu Informacji Naukowej Uniwersytetu Heinrich-Heine w Düsseldorfie (Niemcy).

Oryginalność/Wartość poznawcza: Wartość poznawcza tego artykułu wynika z tego, iż dotychczas opublikowano bardzo niewiele prac szczegółowo odnoszących się do omawianego tematu, których autorami byliby informatolodzy i bibliolodzy, w efekcie czego rola bibliotek w tzw. inteligentnych miastach pozostaje w zasadzie w literaturze naszej dyscypliny niepodjętym tematem. Niniejszy artykuł jest pierwszą taką próbą.
\end{abstract}

\section{Słowa kluczowe}

Bibliologia i informatologia. Biblioteka publiczna. Inteligentna biblioteka. Inteligentne miasto.

MARIUSZ LUTEREK, PhD, is Assistant Professor at the University of Warsaw (Department of Information Studies; Faculty of Journalism, Information and Book Studies). He is the author of many publications on e-government, including the book: e-Government. Public information systems (2010). He was a leader of the project "Libraries as intermediaries in access to public information and services" funded by the National Science Centre of Poland.

Contact to the Author:

m.luterek@uw.edu.pl

Department of Information Studies

Faculty of Journalism, Information and Book Studies, University of Warsaw

Nowy Świat 69

00-927 Warszawa 